\title{
ANALISIS PERENCANAAN STRATEGIS \\ PROGRAM STUDI PENDIDIKAN GURU SEKOLAH DASAR (PGSD) FKIP UNU CIREBON MENGGUNAKAN METODE SWOT
}

\author{
Endang Sri Budi Herawati ${ }^{1}$, Adiman $^{2}$, Rusi Rusmiati Aliyyah ${ }^{3}$ \\ Universitas Nahdlatul Ulama Cirebon ${ }^{1,2}$, Universitas Djuanda Bogor ${ }^{3}$ \\ endangsribudiherawati@gmail.com ${ }^{1}$
}

\begin{abstract}
ABSTRAK
Penelitian ini bertujuan untuk: (1) mengetahui posisi kuadran program studi PGSD FKIP UNU Cirebon menggunakan metode SWOT, (2) mengetahui alternatif strategis jangka pendek yang dapat diterapkan pada prodi PGSD FKIP UNU Cirebon berdasarkan Metode SWOT. Pendekatan penelitian yang digunakan adalah Kualitatif model studi kasus yang didukung dengan data kuantitatif dan penjelasan secara deskriptif. Teknik pengumpulan data menggunakan kuesioner yang terlebih dahulu dilakukan uji validitas dengan teknik validitas isi oleh ahli (expert judgement). Teknik analisis data menggunakan model Miles dan Hubberman. Hasil penelitian menunjukkan bahwa: (1) program studi PGSD berada pada posisi kuadran II dengan kekuatan nilai 0,533 dan ancaman 0,314. (2) strategi yang perlu dilakukan pada prodi PGSD adalah diversifikasi strategi. Simpulan penelitian adalah: (1) prodi PGSD UNU Cirebon berada pada kondisi ornganisasi yang cukup mantap, tetapi menghadapi banyak hambatan (ancaman); (2) Strategi Diversitfikasi yang harus dilakukan adalah meliputi mutu akademik, pelaksanaan Tri Dharma Perguruan tinggi, dan sumber daya manusia.
\end{abstract}

Kata Kunci: Perencanaan Strategi, Metode SWOT, Pendidikan Tinggi

\begin{abstract}
This research aims to: (1) To know the position of quadrant of the PGSD FKIP UNU Cirebon study program using swot method, (2) to know short-term strategic alternatives that can be applied to PGSD FKIP UNU Cirebon based on SWOT Method. The research approach used is a qualitative case study model supported by quantitative data and descriptive explanations. Data collection technique using questionnaire that first performed validity test with expert judgement technique. Data analysis techniques using Miles and Hubberman models. The results showed that: (1) the PGSD study program was in the position of quadrant II with a strength value of 0.533 and a threat 0.314. (2) The strategy that needs to be done in the PGSD FKIP UNU Cirebon is to diversify the strategy. The research conclusions are: (1) the PGSD study program of UNU Cirebon is in a fairly stable condition of ornganization, but faces many obstacles (threats); (2) The diversification strategy that must be carried out is to include academic quality, implementation of The Tri Dharma of Higher Education, and human resources.
\end{abstract}

Keyword: Strategic Planning, SWOT Method, Higher Education 


\section{PENDAHULUAN}

Perguruan tinggi baik negeri maupun swasta dituntut untuk mampu bersaing, dengan memiliki daya saing dan keunggulan sehingga mampu memberikan kontribusi positif bagi kemajuan masyarakat di sekitar wilayah pada khususnya dan masyarakat luas pada umumnya. Daya saing dan keunggulan ini tentu saja berhubungan dengan proses pembelajaran yang dilakukan, produk penelitian yang terpublikasi dan bermanfaat bagi perkembangan ilmu pengetahuan, serta kontribusi perguruan tinggi dalam bidang pengabdian kepada masyarakat yang dilakukan oleh dosen dan mahasiswa. Beberapa riset yang telah dilakukan menunjukkan hasil bahwa perencanaan strategis dibutuhkan bagi pengembangan sebuah program studi/fakultas agar mampu terus bertahan dan bersaing dengan mengidentifikasi berbagai potensi yang ada (Rusnandi \& Susanti, 2012), (Syahrul, 2017), (Fadhillah S \& Waterkamp, 2016), (Wijayanti et al., 2019), (Nita, 2013), (Tyastusi et al., 2014), (Silanegara et al., 2011).

Namun demikian perencanaan strategis yang hanya disusun dengan baik, tetapi tidak dilaksanakan, akan memberikan hasil yang tidak memuaskan. Penelitian yang dilakukan oleh Syahrul menjelaskan bahwa Pendekatan strategik dalam pengelolaan lembaga pendidikan tinggi dapat membangun perguruan tinggi yang berkualitas melalui pengenalan ekternal dan internal sehingga dapat memenuhi harapan pelanggan, namun proses evaluasi terhadap restra harus berjalan dengan baik (Syahrul, 2017). Selanjutnya perencanaan strategik dilakukan dengan mengkaji kekuatan, kelemahan, peluang dan ancaman terhadap perguruan tinggi dapat digunakan untuk menentukan alternatif strategi berdasarkan posisi perguruan tinggi sehingga dimungkinkan untuk terus melakukan ekspansi, memperbesar pertumbuhan dan meraih peluang secara maksimal demi kemajuan yang berkelanjutan (Tyastusi et al., 2014). Sistem informasi juga merupakan faktor pendukung dalam memberikan pelayanan yang baik. Perencanaan strategi sistem informasi mampu memaksimalkan kinerja sistem informasi yang ada melalui analisis lingkungan internal dan eksternal, analisis sistem informasi berjalan, analisis fungsi bisnis, dan pemetaan rencana portofolio aplikasi diwaktu mendatang (Wijayanti et al., 2019). Berdasarkan hasil riset terdahulu jelas bahwa perencanaan strategis menjadi salah satu kebutuhan bagi perguruan tinggi. Perlu adanya evaluasi perencanaan secara berkesinambungan sehingga perguruan tinggi mampu menetapkan alternatif strategi bagi pengembangan lembaga.

Evaluasi terhadap performa dan produktivitas suatu perguruan tinggi harus mempertimbangkan seluruh kegiatan akademik beserta output yang dihasilkan dan dampaknya secara internal maupun eksternal (Viloria et al., 2016). Perencanaan strategis berkaitan dengan dampak masa depan, dan keputusan strategis yang dibuat sekarang. Perencanaan itu mencakup beberapa pilihan yang berkaitan dengan organisasi secara keseluruhan. Perencanaan strategis pada hakekatnya merupakan proses secara sistematis yang berkelanjutan dari pembuatan keputusan yang memiliki resiko, dengan memanfaatkan sebanyak-banyaknya pengetahuan 
antisipatif, mengorganisasi secara sistematis usaha-usaha melaksanakan keputusan tersebut dan mengukur hasilnya melalui umpan balik yang terorganisasi dan sistematis (Kurniawijaya et al., 2019). Perencanaan strategis pada hakekatnya merupakan dokumen perencanaan suatu organisasi/lembaga yang menentukan strategi atau arahan, dan digunakan sebagai dasar dalam mengambil keputusan untuk mengalokasikan sumber daya termasuk modal dan sumber daya manusia dalam mencapai tujuan yang diinginkan (Silitonga, 2019). Perencanaan strategis merupakan upaya yang didisiplinkan untuk membuat keputusan dan tindakan penting yang membentuk dan mengarahkan bagaimana suatu organisasi atau entitas lainnya dan mengapa organisasi (entitas lainnya) mengerjakan hal tersebut (Bryson \& John, 2011).

Beberapa pendapat tentang perencanaan strategis menunjukkan bahwa perencanaan strategis merupakan suatu keharusan bagi sebuah lembaga termasuk lembaga pendidikan untuk dapat mewujudkan tujuan organisasi secara efektif dan efisisen dengan mengoptimalkan segala potensi yang dimiliki. Dengan adanya sebuah perencanaan strategis maka organisasi dapat mempersiapkan tindakantindakan terbaik apa sajakah yang dapat dilakukan untuk mencapai tujuan organisasi. Menjadi jelas bahwa perencanaan strategis merupakan rencana dasar atau cetak biru (blue print) yang berisi tindakan-tindakan penting dan menjadi pedoman bagi seluruh level organisasi, dimana pimpinan lembaga dapat fokus pada tujuan utama terutama terkait dengan pelanggan, serta menjauhkan perhatian atas rutinitas.

Manfaat dari perencanaan strategis yang dibuat oleh suatu organisasi secara rinci dijelaskan oleh Steiner, dkk yaitu dapat membantu suatu organisasi untuk: (1) Berpikir secara strategis dan mengembangkan strategi-strategi yang efektif; (2) Memperjelas arah masa depan; (3) Menciptakan prioritas; (4) Membuat keputusan sekarang dan mengingat konsekuensi masa depan; (5) Mengembangkan landasan yang koheren dan kokoh bagi pembuatan keputusan; (6) Menggunakan keleluasaan yang maksimum dalam bidang-bidang yang berada dibawah kontrol organisasi; (7) Membuat keputusan yang melintasi tingkat dan fungsi; (8) Memecahkan masalah utama organisasi; (9) Memperbaiki kinerja organisasi; (10) Memperbaiki kinerja organisasi; dan (11) Membangun kerja kelompok dan keahlian. Keahlian merupakan prioritas dari organisasi (Bryson \& John, 2011). Adapun tahapan yang perlu dilakukan dalam menyusun sebuah rencana strategis adalah dengan memperhatikan: (1) visi, misi, dan tujuan; (2) analisis pasar; (3) analisis SWOT; (4) perencanaan operasi dan bisnis; (5) kebijakan dan perencanaan mutu; (6) biaya mutu; (7) monitoring dan evaluasi (Sallis, 2010). Sementara itu, Hill dan Jones menjelaskan bahwa langkah yang perlu dilakukan dalam proses perencanaan strategis adalah meliputi: (1) pemilihan misi perusahaan dan tujuantujuan perusahaan yang utama; (2) analisis lingkungan eksternal persaingan organisasi untuk mengidentifikasi peluang dan tantangan; (3) analisis lingkungan operasi internal organisasi untuk mengenali kekuatan dan 
kelemahan; (4) pemilihan strategi yang dibangun di atas kekuatan organisasi dan memperbaiki kelemahannya yang patut untuk mengambil keunggulan dari peluang eksternal dan melawan hambatan eksternal (SWOT); dan (5) implementasi strategi (Hill \& Jones, 1998). Sebagai perencanaan dalam skala besar, perencanaan strategis memperhitungkan keterlibatan segenap pemangku kepentingan organisasi. Para pemangku kepentingan (stakeholder) internal maupun eksternal mesti diberikan ruang-ruang tertentu untuk terlibat memberi sumbangsih dalam sebuah rencana strategis.

Unsur sentral perencanaan strategis bidang publik terdapat pada akronim SWOT, yang diangkat dari model kebijakan Harvard. SWOT merupakan kepanjangan dari strengths (kekuatan), weaknesses (kelemahan), opportunities (peluang), dan threats (ancaman), yang dikaji dari masyarakat, sebagai dasar bagi penyusunan strategi untuk mencapai tujuan dan sasaran dalam bidang isu-isu kunci (Syahrul, 2015). Walaupun demikian, penting dicatat bahwa analisis SWOT memiliki keterbatasan, sebagaimana ditegaskan oleh Eisner et.al bahwa SWOT tidak dapat menunjukkan bagaimana mencapai keunggulan bersaing, mereka tidak harus membuat tujuan analisis SWOT itu sendiri, sementara mengangkat kesadaran tentang isu-isu penting tetapi lemah mengambil tindakan penting untuk membuat perubahan strategis (Dess et al., 2008). Fredy Rangkuti menjelaskan bahwa analisis SWOT merupakan identifikasi berbagai faktor secara sistematis untuk merumuskan strategi sebuah organisasi, dimana Analisa yang dilakukan adalah didasarkan pada hubungan atau interaksi antara unsur-unsur internal yaitu kekuatan dan kelemahan, terhadap unsur-unsur eksternal yaitu peluang dan ancaman (Rangkuti, 2011).

\section{METODE PENELITIAN}

Penelitian ini merupakan penelitian studi kasus dengan pendekatan motode SWOT. Pengumpulan data dilakukan menggunakan angket didukung dengan hasil observasi dan studi dokumentasi program studi PGSD. Sampel dalam penelitian ini berjumlah 64 orang dengan responden yang dipilih secara random. Sampel terdiri dari seluruh dosen di lingkungan program studi PGSD sebanyak 14 orang sedangkan sisanya sebanyak 30 orang mahasiswa aktif dan 20 orang alumni. Uji validitas untuk data kualitatif menggunakan triangulasi teknik, sedangkan uji validitas untuk data kuantitaf dilakukan dengan uji validitas isi yang dikonsultasikan dengan para ahli (expert judgment). Teknis analisis data dilakukan dengan model Milles dan Huberman melalui empat tahap yaitu: (1) pengumpulan data (data collecting); (2) reduksi data (reduction data); (3) penyajian data (display data); dan (4) pengambilan kesimpulan (verification). Komponen analisis data ditunjukkan pada gambar 1 berikut ini: 


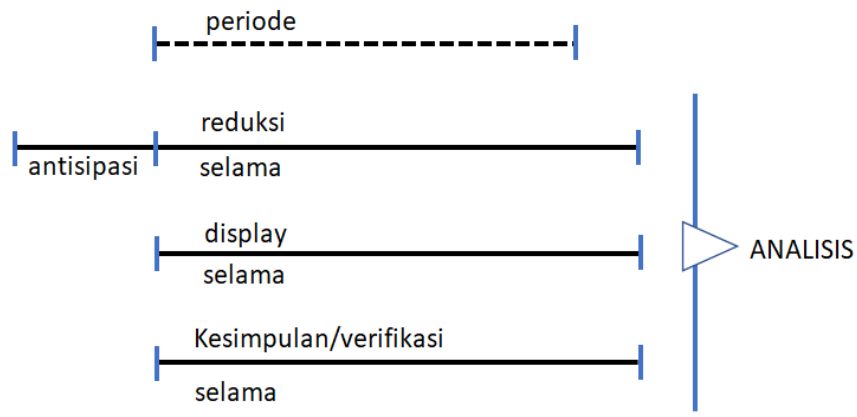

Gambar 1. Komponen dalam Analisis Data (flow model) (Sugiyono, 2011)

Berdasarkan gambar 1 terlihat bahwa setelah melakukan pengumpulan data, langkah selanjutnya adalah melakukan antisipatory sebelum melakukan reduksi data. Display penelitian merupakan hasil rekapitulasi perhitungan SWOT dengan penyajian data dalam bentuk grafik dari sembilan isu strategis yang ditetapkan, yaitu: (1) visi misi; (2) tata pamong/manajemen; (3) kemahasiswaan dan alumni; (4) SDM dosen dan tenaga pendukung; (5) kurikulum; (6) proses pembelajaran dan suasana akademik; (7) pembiayaan; (8) sarana prasarana; dan (9) penelitian \& PkM. Titik koordinat pada kuadran diperoleh dari hasil perhitungan SWOT sesuai rumus yang ditentukan. Hal ini dilakukan dengan terlebih dahulu menetapkan bobot pada setiap indikator dari isu-isu strategis. Untuk memudahkan perhitungan, digunakan kriteria prosentasi dari 0 s.d. $100 \%$, jadi total prosentasi dari masingmasing isu strategis berjumlah 100\%. Penetapan kuadran yang didapat dari perhitungan SWOT ditunjukan menggunakan sistem koordinat kartesius dimana jumlah pengurangan antara skor total kekuatan (S) dan kelemahan (W) menjadi koordinat $\mathrm{X}$ (absis) sedangkan jumlah pengurangan antara skor total peluang (O) dan ancaman (T) menjadi koordinat Y (ordinat). Kesimpulan yang didapat dalam perhitungan analisis SWOT ini digunakan untuk menentukan alternatif strategi dari sembilan isu strategis yang disusun. Selanjutnya, digunakan untuk menganalisis renstra dengan strategi alternatif yang disusun berdasarkan faktor internal (kekuatan dan kelemahan) serta faktor eksternal (peluang dan ancaman) suatu program. Dengan demikian analisis SWOT dilakukan untuk mengkaji kekuatan, kelemahan, peluang dan ancaman dari isu-isu strategis yang ditetapkan, sehingga akan didapat posisi kuadran yang menggambarkan situasi nyata pada suatu organisasi.

\section{HASIL PENELITIAN}

Berdasarkan hasil analisis SWOT seluruh indikator dari sembilan isu strategis yang ditetapkan dalam perencanaan strategis pada program studi PGSD FKIP UNU Cirebon, diperoleh hasil sebagai berikut: 
Tabel 1. Hasil Perhitungan Analisis SWOT Prodi PGSD FKIP UNU Cirebon

\begin{tabular}{lc}
\hline Komponen Analisis SWOT & Total Nilai (Bobot X Skor) \\
\hline Kekuatan (Strength) & 2,065 \\
\hline Kelemahan (Weakness) & 1,532 \\
\hline Peluang (Opportunity) & 2,412 \\
\hline Ancaman/Hambatan (Threat) & 2,726 \\
\hline Sumber: hasil penelitian yang diolah &
\end{tabular}

Berdasarkan tabel 1 dapat disimpulkan bahwa posisi program studi PGSD FKIP UNU Cirebon adalah sebagai berikut:

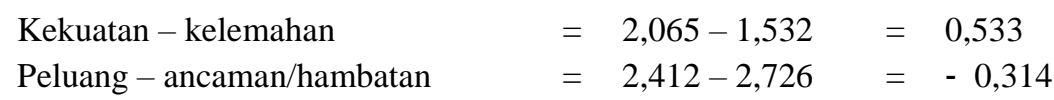

Nilai pengurangan kekuatan dan kelemahan serta peluang dan ancaman/hambatan dapat digambarkan pada diagram kartesius berikut:

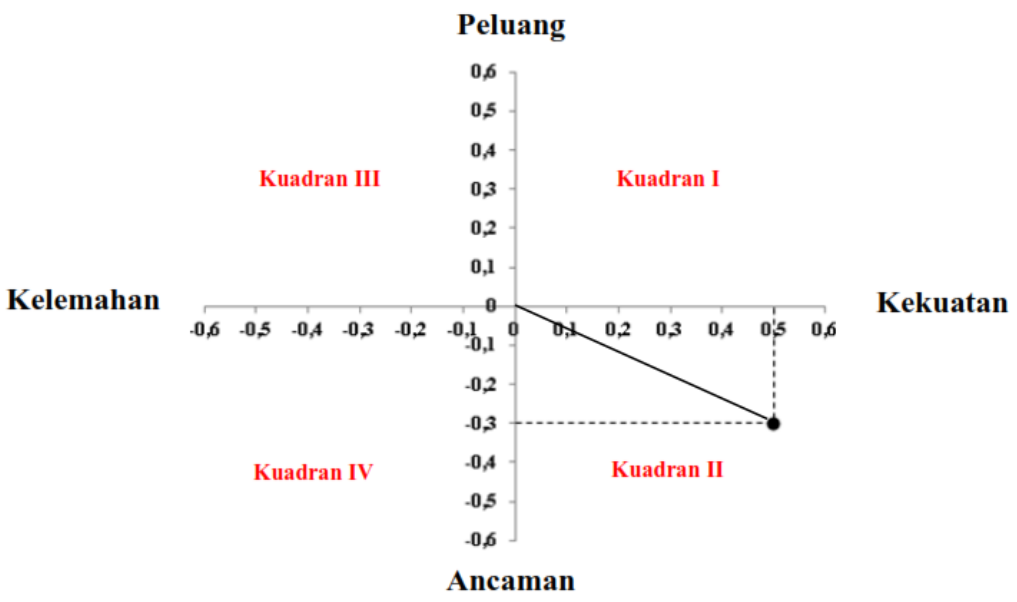

Gambar 2. Diagram Kartesius Hasil Analisis SWOT

Gambar 2 menunjukkan pemetaan keseimbangan skor yang menunjukkan posisi Program Studi PGSD FKIP UNU Cirebon yaitu pada sumbu X = 0,533 dan sumbu $\mathrm{Y}=-0,314$. Hasil ini menunjukkan bahwa Program Studi PGSD berada pada posisi kuadran II, yang berarti bahwa Prodi PGSD UNU Cirebon berada pada kondisi organisasi yang cukup mantap, tetapi menghadapi banyak hambatan (ancaman). Untuk itu perlu dilakukan diversifikasi strategi.

Berdasarkan hasil Analisa faktor internal dan eksternal yang ada, maka program studi PGSD FKIP UNU Cirebon dapat melakukan beberapa strategi sebagai berikut:

1. Strategi $(\boldsymbol{S}-\boldsymbol{O})$, artinya menggunakan "S" strength (kekuatan) untuk memanfaatkan "O" opportunity (peluang). Langkah yang dapat dilakukan 
dalam melaksanakan strategi ini adalah: (a) Pengembangan kurikulum sesuai visi, misi, sasaran dan tujuan program studi dengan memperhatikan kebutuhan berbagai stakeholder; (b) Meningkatkan pemanfaatan kemajuan iptek dalam pencapaian visi misi; (c) Meningkatkan Kerjasama yang saling menguntungkan dengan berbagai pihak baik pemerintah maupun swasta; (d) Meningkatkan kualitas lulusan melalui peningkatan tata kelola, SDM, dan sarana prasarana; (e) Meningkatkan efisiensi dan efektifitas tata pamong melalui penggunaan teknologi informasi dan komunikasi (TIK); (f) Menjalin kerjasama dengan berbagai Lembaga baik dalam maupun luar negeri pada bidang keahlian Pendidikan dasar seusai tuntutan stakeholder; $(g)$ Meningkatkan kerjasama yang saling menguntungkan dengan berbagai pihak baik pemerintah maupun swasta; (h) Menjaga loyalitas dan integritas dosen dan tenaga pendukung (tendik); (i) Meningkatkan keikutsertaan dosen dalam kegiatan akademik baik di tingkat regional, nasional, maupun internasional; (j) Meningkatkan optimalisasi pengelolaan anggaran dan keuangan; (k) Meningkatkan sumber pendanaan dari implementasi kegiatan kerjasama baik dengan pemerintah maupun swasta; (1) Membangun Kerjasama penelitian dengan berbagai pihak, baik pemerintah maupun swasta; (m) Meningkatkan jumlah penelitian dosen yang relevan dengan bidang keilmuan masingmasing; (n) Meningkatkan kerjasama yang saling menguntungkan dengan berbagai pihak baik pemerintah maupun swasta khususnya dalam kegiatan penelitian dan pengabdian kepada masyarakat.

2. Strategi $(\boldsymbol{W}-\boldsymbol{O})$, artinya menghilangkan "W" weakness (kelemahan) dan memanfaatkan "O" opportunity (peluang). Langkah yang dapat dilakukan dalam melaksanakan strategi ini adalah: (a) Mengoptimalkan pemahaman visi, misi, tujuan dan sasaran prodi PGSD UNU Cirebon; (b) Meningkatkan kualitas sumber daya yang sesuai dengan kebutuhan; (c) Mengoptimalkan pemahaman implementasi tata nilai prodi secara konsisten oleh sivitas akademika; (d) Melakukan studi banding dan benchmarking pada perguruan tinggi lain sejenis untuk melakukan perbaikan kurikulum, serta merintis kerjasama dengan perguruan tinggi lain dalam pelaksanaan Tri Dharma Perguruan Tinggi; (e) Menjaga komitmen konsistensi hasil evaluasi terhadap implementasi replacement activity, development activity, dan improvement activity; (f) Meningkatkan promosi dan citra UNU Cirebon dimata masyarakat; (g) Meningkatkan kompetensi lulusan melalui perbaikan proses pembelajaran, pembekalan soft skill, dan kompetensi pendukung lainnya; (h) Meningkatkan kompetensi dosen dalam mendapatkan beasiswa studi lanjut S3; (i) Meningkatkan kerjasmaa yang saling menguntungkan dengan berbagai pihak baik pemerintah maupun swasta; (j) Melakukan peningkatan kualitas dosen melalui berbagai pelatihan yang diselenggarakan Kemenristekdikti atau pun pihak lain; (k) Meningkatkan kualitas layanan akademik dan non akademik kepada mahasiswa, serta menambah jumlah 
sarana prasarana agar mampu memberikan pelayanan dengan lebih baik; (1) Mengoptimalkan penggunaan sistem informasi dalam rangka meningkatkan efektifitas pengambilan keputusan dan kebijakan; (m) Meningkatkan jumlah penelitian dengan memanfaatkan sumber dana dari hibah pemerintah dan instansi swasta lainnya; (n) Meningkatkan jumlah publikasi hasil penelitian dosen pada jurnal nasional maupun internasional dan buku.

3. Strategi $(\boldsymbol{S}-\boldsymbol{T})$, artinya menggunakan "S" strength (kekuatan) untuk menghindarkan "T" treath (ancaman/hambatan). Langkah yang dapat dilakukan dalam melaksanakan strategi ini adalah: (a) Meningkatkan sosialisasi/promosi mengenai visi misi tujuan dan sasaran prodi kepada seluruh dosen dan mahasiswa (pemangku kepentingan), serta senantiasa mengevaluasi dan melakukan perbaikan terhadap penerapan yang dinilai belum sesuai; (b) Meningkatkan secara berkelanjutan dan periodik sosialisasi/promosi mengenai visi misi tujuan dan sasaran prodi kepada seluruh dosen dan mahasiswa (pemangku kepentingan), serta senantiasa mengevaluasi dan melakukan perbaikan terhadap penerapan yang dinilai belum sesuai; (c) Meningkatkan peran serta dan keterlibatan alumni dalam proses pembelajaran dalam upaya meningkatkan kompetensi dan skill lulusan; (d) Meningkatkan kerjasama dengan alumni baik dalam hal akademik maupun non akademik, serta mengoptimalkan kerjasama dengan pihak swasta; (e) Mempertahankan dan menjaga stabilitas rasio dosen terhadap mahasiswa agar tercapai kualitas pembelajaran yang optimal; (f) Meningkatkan kualitas dosen dan tenaga kependidikan (tenaga pendukung) melalui berbagai kegiatan akademik, pelatihan, dan studi lanjut guna meningkatkan daya saing SDM prodi PGSD UNU Cirebon; (g) Menerapkan kurikulum sesuai KKNI sehingga mutu lulusan mampu memenuhi kebutuhan masyarakat; (h) Meningkatkan proses pembelajaran dan suasana akademik sehingga mampu menghasilkan lulusan yang berkualitas dan mampu mengikuti perubahan yang terjadi di masyarakat; (i) Optimalisasi pemanfaatan sarana dan prasarana serta fasilitas penunjang lainnya, dalam rangka pelaksanaan dan pengembangan Tri Dharma Perguruan Tinggi khususnya peningkatan kualitas pembelajaran dan suasasna akademik secara berkelanjutan; (j) Meningkatkan pengembangan sarana dan prasarana serta fasilitas penunjang yang dapat mendukung tercapainya visi misi; (k) Meningkatkan sistem informasi untuk menunjang kemudahan akses program studi, fakultas, dan universitas terkait dengan kegiatan Tri Dharma Perguruan Tinggi; (l) Meningkatkan kualitas dan pemanfaatan hasil penelitian dan pengabdian kepada masyarakat; (m) Meningkatkan kualitas peneliti; (n) Meningkatkan kualitas dan kuantitas penelititan dan pengabdian kepada masyarakat baik tanpa ataupun dengan melibatkan mahasiswa; (o) Meningkatkan jumlah publikasi ilmiah pada jurnal nasional dan internasional; (p) Meningkatkan dukungan institusi dalam memfasilitasi perolehan hibah penelitian dan pengabdian masyarakat baik 
yang bersumber dari pemerintah maupun swasta; (q) Meningkatkan dukungan Yayasan dalam peningkatan jumlah sarana prasarana dalam penyelenggaraan Tri Dharma Perguruan tinggi.

4. Strategi $(\boldsymbol{W}-\boldsymbol{T})$, artinya meminimalkan "W" weakness (kelemahan) untuk menghindarkan " $T$ " treath (ancaman/hambatan). Langkah yang dapat dilakukan dalam melaksanakan strategi ini adalah: (a) Meningkatkan optimalisasi sumber daya yang dipergunakan dalam implementasi strategi pencapaian visi misi tujuan dan sasaran prodi PGSD; (b) Peningkatan keterlibatan stakeholder eksternal dalam pencapaian visi misi tujuan dan sasaran prodi PGSD; (c) Meningkatkan nilai akreditasi prodi; (d) Meningkatkan kompetensi dosen dan tenaga kependidikan (tenaga pendukung) secara berkelanjutan; (e) Meningkatkan optimalisasi pemanfaatan hasil evaluasi internal dan eksternal dalam pengembangan dan perbaikan yang berkelanjutan; (f) Meningkatkan sarana dan prasarana sesuai kebutuhan proses belajar mengajar yang baik dan dibutuhkan, berdasarkan tuntutan kurikulum; (g) Meningkatkan optimalisasi sistem informasi dan basis data yang ada; (h) Meningkatkan optimalisasi penggunaan sistem informasi pada seluruh kegiatan Tri Dharma Perguruan Tinggi; (i) Meningkatkan optimalisasi sumber daya dalam kegiatan penelitian dan pengabdian kepada masyarakat; (j) Meningkatkan produktivitas dosen dalam kegiatan penelitian dan pengabdian kepada masyarakat; (k) Meningkatkan produktivitas dosen dalam melakukan publikasi hasil penelitian pada jurnal nasional dan internasional.

\section{PEMBAHASAN}

Program studi PGSD FKIP UNU Cirebon yang saat ini berada pada kuadran II dimana organisasi ada pada kondisi cukup mantap tetapi menghadapi banyak hambatan. Oleh karenanya perlu melakukan diversifikasi strategi agar mampu bertahan dan bersaing dengan prodi sejenis. Penetapan strategi ini perlu dilakukan berdasarkan pemahaman terhadap kekuatan yang dimiliki oleh lembaga (faktor internal) serta tantangan dan hambatan yang ada di sekitar (faktor eksternal). Dengan demikian prodi dapat menetapkan arah/strategi pengembangan yang tepat. Hal ini sejalan dengan riset yang dilakukan oleh Syahrul yang menyatakan bahwa tuntutan membangun perguruan tinggi berkualitas mensyaratkan pengenalan yang baik terhadap kondisi eksternal dan penguatan internal (Syahrul, 2017). Diversifikasi strategi yang dapat ditempuh oleh program Studi PGSD FKIP UNU Cirebon ini, menuntut komitmen seluruh komponen sivitas akademika termasuk di tataran fakultas dan universitas. Langkah-langkah dalam diversifikasi strategi berdasarkan hasil Analisa SWOT di atas kemudian perlu dibuat strategi pengembangan secara konkrit sebagai yang meliputi beberapa bidang yaitu: (1) pengembangan mutu akademik; (2) peningkatan produktivitas penelitian dan pengabdian masyarakat; (3) peningkatan dan pengembangan manajemen internal dan organisasi; (4) 
peningkatan dan pengembangan mutu sumber daya manusia; (5) peningkatan dan pengembangan mutu sarana prasarana.

Strategi peningkatan dan pengembangan mutu akademik dilakukan dengan beberapa langkah yaitu: (1) Meningkatkan dan mengembangkan pelaksanaan proses pembelajaran yang berpusat pada mahasiswa (based student centre learning); (2) Melakukan studi banding dan bechmarking dalam rangka evaluasi kurikulum menuju kurikulum berbasis kompetensi yang relevan sesuai kebutuhan pengguna lulusan; (3) Meningkatkan dan mengembangkan kurikulum yang relevan dalam kerangka KKNI; (4) Merintis kerjasama dengan perguruan tinggi negeri sebagai bapak asuh dalam merancang kurikulum yang berdaya saing; (5) Meningkatkan kompetensi lulusan melalui perbaikan proses pembelajaran berbasis kompetensi dan penguasaan softskill; (6) Meningkatkan pembentukan karakter ahlussunnah waljama'ah sebagai nafas dalam pelaksanaan dan pengembangan Tri Dharma Perguruan Tinggi, kepada seluruh sivitas akademika; (7) Meningkatkan kompetensi dan skill lulusan serta meningkatkan kerjasama dengan alumni; (8) Meningkatkan dan mengembangkan kerjasama yang telah terbangun dengan berbagai institusi, sehingga dapat meningkatkan bidang keahlian/kompetensi lulusan sesuai dengan tuntutan pengguna (stakeholder).

Selanjutnya peningkatan produktivitas penelitian dan pengabdian masyarakat juga merupakan salah satu bidang yang perlu untuk terus ditingkatkan sehingga prodi mampu bertahan dan terus berkembang untuk kemajuan yang berkelanjutan. Upaya utama yang dapat dilakukan adalah dengan memperbanyak kolaborasi riset dosen dan mahasiswa. Upaya ini sejalan dengan hasil riset Sari Tyastuti, dkk yang menyatakan bahwa dengan memaksimalkan mahasiswa dalam penelitian paying, akan sangat bermanfaat baik bagi dosen serta membantu mahasiswa dalam penyusunan skripsi dan mempercepat masa studinya, sebagai upaya menggunakan semua kekuatan untuk mengatasi ancaman yang berasal dari luar sehingga mampu mendukung prodi untuk berkembang secara optimal (Tyastusi et al., 2014). Bentuk operasional dari strategi peningkatan produktivitas penelitian dan pengabdian kepada masyarakat yang dapat diterapkan prodi PGSD UNU Cirebon adalah: (1) Meningkatkan budaya meneliti dan menulis dikalangan dosen dan mahasiswa dengan optimalisasi riset kolaborasi dosen dan mahasiswa; (2) Meningkatkan partisipasi dan kemampuan peneliti untuk menghasilkan riset-riset yang relevan dengan bidang keilmuan; (3) Meningkatkan hasil produk penelitian yang berorientasi pada inovasi, pemecahan masalah dan pengembangan ilmu bidang pendidikan dasar; (4) Meningkatkan kegiatan pengabdian masyarakat yang berbasis riset yang dapat menjadi solusi/pemecahan masalah dan permberdayaan masyarakat; (5) Meningkatkan jumlah penelitian dengan memanfaatkan sumber dana dari eksternal kampus, baik swasta maupun pemerintah (Kemendikbud); (6) Meningkatkan kualitas penelitian dengan membangun kerjasama dalam bentuk research collaboration dengan perguruan tinggi lain baik negeri maupun swasta; (7) Meningkatkan kemampuan 
dosen dalam menulis artikel ilmiah; (8) Meningkatkan diseminasi hasil penelitian melalui publikasi pada jurnal terindeks baik nasional maupun internasional, serta meningkatkan perolehan paten dan HKI; (9) Meningkatkan dukungan institusi dalam memfasilitasi perolehan hibah penelitian dan pengabdian masyarakat baik yang bersumber dari pemerintah maupun swasta.

Dapat dipahami bahwa manajemen organisasi yang baik merupakan hal yang berkontribusi cukup signifikan dalam pencapaian tujuan organisasi. Kunci sukses institusi/lembaga sangat ditentukan oleh rumusan, proses perumusan dan konsistensi pelaksanaan visi, misi dan tujuan strategis dari institusi/lembaga tersebut (Silitonga, 2019). Dalam manajemen organisasi, dibutuhkan adanya sebuah perencanaan yang baik. Perencanaan strategi dirumuskan untuk menjawab persoalan-persoalan kekinian organisasi dan masa depan yang panjang, sehingga di dalamnya mencakup seperangkat kegiatan dan hasil spesifik yang akan dilakukan dan dicapai (Syahrul, 2017). Adapun Strategi peningkatan dan pengembangan manajemen internal dan organisasi, yang dapat dikembangkan pada prodi PGSD UNU Cirebon adalah: (1) Mengoptimalkan pemahaman visi, misi, tujuan, dan sasaran program studi PGSD baik kepada sivitas akademika maupun stakeholder eksternal sebagai acuan dalam gerak langkah pelaksanaan program untuk mencapai visi misi tujuan dan sasaran prodi; (2) Meningkatkan secara berkelanjutan dan periodik, sosialisasi visi, misi, tujuan, dan sasaran program studi kepada seluruh dosen dan mahasiswa (pemangku kepentingan) serta melakukan evaluasi dan perbaikan terhadap penerapan yang dinilai kurang sesuai; (3) Mengoptimalkan pemahaman dan implementasi tata nilai program studi secara konsisten dan berkesinambungan kepada sivitas akademika; (4) Meningkatkan promosi dan citra UNU Cirebon pada umumnya dan prodi PGSD serta fakultas pada khususnya, di masyarakat; (5) Benchmarking dengan perguruan tinggi negeri dan merintis kerjasama dalam pelaksanaan Tri Dharma Perguruan Tinggi; (6) Meningkatkan kerjasama yang saling menguntungkan dengan berbagai pihak baik pemerintah maupun swasta.

Selanjutnya, bidang yang perlu diperhatikan untuk terus ditingkatkan agar prodi PGSD UNU Cirebon mampu bertahan ditengah banyaknya ancaman adalah pengembangan mutu sumber daya manusia. Zachman dalam Yunus Fadhillah, dkk menyebutkan bahwa pengembangan sumber daya manusia pada setiap departemen terutama pada Information Communication Technology (ICT) menggunakan konsep berpikir dengan menerapkan dan melak- sanakan kegiatan kerja setiap individu berbasis What, How, Where, Who, When dan Why dalam setiap pengembangannya (Fadhillah S \& Waterkamp, 2016). Adapun strategi yang dapat dilakukan terkait hal tersebut adalah: (1) Mempertahankan dan menjaga stabilitas rasio dosen terhadap mahasiswa agar tercapai kualitas pembelajaran yang optimal; (2) Meningkatkan kualitas dosen dan tenaga kependidikan (tenaga pendukung) melalui berbagai kegiatan akademik, dan pelatihan guna meningkatkan daya saing SDM; (3) Meningkatkan keikutsertaan dosen dalam 
kegiatan akademik baik yang diselenggarakan oleh pemerintah (Kemendikbud dan Kemenristekbrin) maupun Lembaga lain; (4) Meningkatkan kompetensi dosen untuk studi lanjut S3 melalui perolehan beasiswa baik dalam maupun luar negeri.

Adapun strategi berikutnya yang perlu dilakukan agar semakin mantap dan siap menghadapi ancaman/hambatan, maka prodi PGSD UNU Cirebon perlu melakukan peningkatan dan pengembagan mutu sarana dan prasarana pendidikan yang meliputi: (1) Optimalisasi pemanfaatan sarana dan prasarana serta fasilitas penunjang lainnya dalam rangka pelaksanaan dan pengembangan Tri Dharma Perguruan Tinggi khususnya peningkatan kualitas pembelajaran dan suasana akademik secara berkelanjutan; (2) Meningkatkan pengembangan sarana dan prasarana serta fasilitas penunjang yang dapat mendukung tercapainya visi misi; (3) Meningkatkan sistem informasi untuk menunjang kemudahan akses program studi, fakultas, dan universitas terkait kegiatan Tri Dharma Perguruan Tinggi; (4) Meningkatkan sarana dan prasarana sesuai kebutuhan proses pembelajaran yang diharapkan dalam pencapaian kurikulum; (5) Meningkatkan dan mengembangkan optimalisasi sistem informasi dalam pengelolaan sarana dan prasarana; (6) Meningkatkan kualitas layanan dan ketersediaan sarana prasarana; (7) Meningkatkan dukungan Yayasan dalam peningkatan jumlah sarana prasarana dalam penyelenggaraan Tri Dharma Perguruan Tinggi.

\section{SIMPULAN}

Program studi PGSD FKIP UNU Cirebon berada pada posisi kuadran II yang memiliki makna bahwa prodi PGSD berada pada kondisi organisasi yang cukup mantap, tetapi menghadapi banyak hambatan (ancaman). Strategi yang perlu diterapkan pada program studi PGSD FKIP UNU Cirebon adalah diversifikasi strategi sehingga dapat mempertahankan diri dan terus berkembang serta meraih peluanh secara maksimal demi kemajuan yang berkelanjutan. Adapun Diversifikasi strategi yang perlu dilakukan adalah meliputi: (1) peningkatan dan pengembangan mutu akademik; (2) peningkatan produktivitas penelitian dan pengabdian masyarakat; (3) peningkatan dan pengembangan manajemen internal dan organisasi; (4) peningkatan dan pengembangan mutu sumber daya manusia; (5) peningkatan dan pengembangan mutu sarana prasarana. 


\section{DAFTAR PUSTAKA}

Bryson, \& John, M. (2011). Strategic Planning For Public and Non Profit Organization; A Guide to Strengthening and Sustaining Organization Achievement. San Fransisco: Jossey Bass.

Dess, G., Gregory, Lumpkin, G. T., \& Eisner, A. B. (2008). Strategic Management: Text and Cases, Fourth Edition. New York: McGraw Hill.

Fadhillah S, Y., \& Waterkamp, J. (2016). Analisa dan Perencanaan Strategis Sistem dan Teknologi Informasi Menggunakan Balance Scorecard pada Institut Bisnis dan Informatika Kwik Kian Gie. Jurnal Sistem Informasi, 12(1), 17. https://doi.org/10.21609/jsi.v12i1.457

Hill, C. W. L., \& Jones, G. R. (1998). Strategic Management: An Integrated Approach. Boston: Houghton Mifflin Company.

Kurniawijaya, P. A., Wiharta, D. M., \& Sastra, N. P. (2019). Perencanaan Strategis Menuju Webometrics dan 4ICU Pada Website Perguruan Tinggi. Majalah Ilmiah Teknologi Elektro, 18(1), 95. https://doi.org/10.24843/MITE.2019.v18i01.P14

Nita, S. (2013). Analisis dan Perencanaan Strategis Teknologi Informasi di Perguruan Tinggi dengan Metode Zachman (Studi Kasus di STT Dharma Iswara Madiun). Konferensi Nasional Teknologi Informasi Dan Komunikasi (KNASTIK) ISSN: 2338-7718.

Rangkuti, F. (2011). SWOT Balanced Scorecard; Teknik Menyusun Strategi Korporat yang Efektif Plus Cara Mengelola Kinerja dan Resiko. Jakarta: Gramedia Pustaka Utama.

Rusnandi, E., \& Susanti, D. (2012). Perencanaan Strategis Cloud Computing Technology Berbasis Gafe (Google APPs for Education) bagi Perguruan Tinggi Swasta di Wilayah III Cirebon Propinsi Jawa Barat. Jurnal Computech \& Bisnis, 6(1), 1-16. http://jurnal.stmikmi.ac.id/index.php/jcb/article/view/93/109

Sallis, E. (2010). Total Quality Management in Education. Jakarta : IRCiDSoD.

Silanegara, I., Tama, B. A., Nurhidayat, D., \& Adi, M. H. (2011). Perencanaan Strategis Teknologi Informasi (Studi Kasus: Politeknik Negeri Jakarta). Junal Generic, 6(1). http://journal.portalgaruda.org/index.php/generic/article/view/124

Silitonga, D. (2019). Komparasi Perencanaan Strategis (Renstra) Kemendikbud dan SMA 68 Jakarta Berdasarkan Analisis Teori. Jurnal Manajemen Bisnis, 22(2), 141-160. https://ibn.e-journal.id/index.php/ESENSI/article/view/165

Sugiyono. (2011). Metode Penelitian Pendidikan: Pendekatan Kuantitatif, Kualitatif, dan $R \& D$. Bandung: Alfabeta.

Syahrul. (2015). Mengelola Perguruan Tinggi dalam Iklim Ketidakpastian (Memahami Dinamika Perencanaan Strategis) di STAIN Sultan Qaimuddin Kendari. Jurnal Hasil-Hasil Penelitian (Al-Izzah), 10(1), 143-160. https://doi.org/10.31332/ai.v10i1.332

Syahrul. (2017). Perencanaan Strategis dan Praktiknya di Perguruan Tinggi. Shautut Tarbiyah, IAIN Kendari, 23(1), 1-17. https://doi.org/http://dx.doi.org/10.31332/str.v23i1.584 
Tyastusi, S., Suharno, \& Sudibyo, C. (2014). Analisis Perencanaan Strategis Program Studi Pendidikan Teknik Mesin JPTK FKIP UNS menggunakan Metode SWOT. Jurnal Ilmiah Pendidikan Teknik Mesin (NOSEL), 3(2). https://jurnal.fkip.uns.ac.id/index.php/ptm/article/view/8207/5967

Viloria, A., Samuel, M. T., Vásquez, C. L., Varela, N., Cabrera, D., \& GaitánAngulo, M. (2016). Ranking of scientific visibility of Latin American universities. Journal of Control Theory and Applications. ISSN, 0974-5572.

Wijayanti, R., Soedijono, B., \& Arief, M. R. (2019). Meningkatkan Keunggulan Bersaing dengan Perencanaan Strategis Sistem Informasi pada Perguruan Tinggi ABC. Jurnal Voice of Informatic (VOI), 8(2). https://voi.stmiktasikmalaya.ac.id/index.php/voi/article/view/182/67 